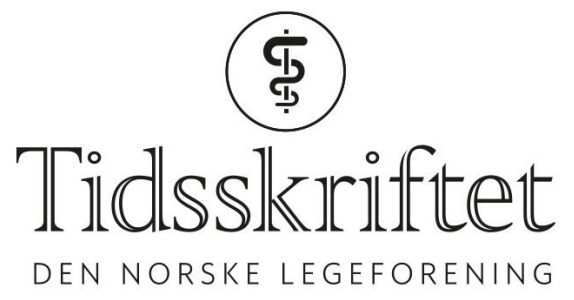

\title{
Genvariant assosiert med autoimmun sykdom
}

FRA ANDRE TIDSSKRIFTER

KARI TVEITO

Tidsskriftet

En genvariant som gir høye nivåer av B-celleaktiverende faktor beskytter mot malaria, men gir $\emptyset \mathrm{kt}$ risiko for multippel sklerose og systemisk lupus erythematosus, viser en studie fra Sardinia.

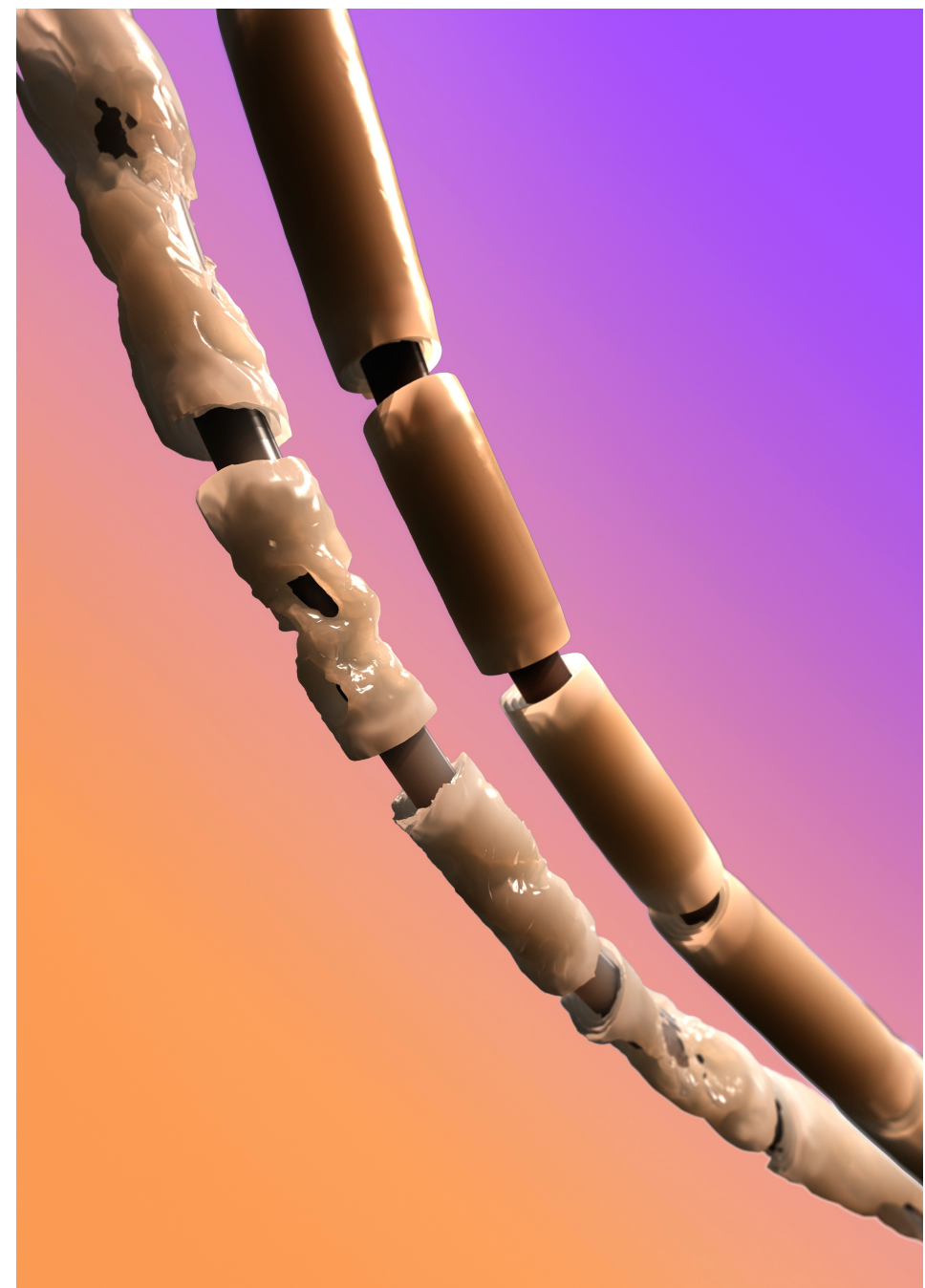

Foto: Science Photo Library 
Prevalensen av multippel sklerose og systemisk lupus erythematosus på den italienske øya Sardinia er blant de høyeste i verden. I en genomvid assosiasjonsstudie ble genomet fra nesten 3 ooo pasienter med multippel sklerose og om lag 400 pasienter med systemisk lupus erythematosus sammenlignet med over 10 ooo kontrollpersoner, alle med bosted på Sardinia (1).

En variant av TNFSF13B-genet, som koder for et cytokin kalt B-celleaktiverende faktor (BAFF), var assosiert med både multippel sklerose og systemisk lupus erythematosus. Mutasjonen i risikoallelet viste seg å gi et kortere RNA-transkript, noe som igjen ga økt BAFF-produksjon. BAFF er svært viktig for aktivering, differensiering og aktivering av B-celler.

Genetiske signaturer i populasjonen indikerte at genvarianten BAFF-var er blitt positivt selektert på Sardinia, muligens fordi økt humoral immunitet gir bedre beskyttelse mot malaria, som var en vanlig sykdom på øya frem til 1950-årene.

- Dette er en svært grundig og omfattende studie, sier Hanne Flinstad Harbo, som er professor og overlege i nevrologi ved Oslo universitetssykehus. - Ved hjelp av store pasientpopulasjoner, genscreening og avanserte molekylærbiologiske teknikker har man for første gang klart å vise at en insersjon-delesjon-variant i genet som koder for BAFFmolekylet leder til økt humoral immunitet. Denne genvarianten er forbundet med $ø \mathrm{kt}$ risiko for både multippel sklerose og systemisk lupus erythematosus. Samtidig har varianten gitt en evolusjonsmessig fordel ved å beskytte mot malaria. Det neste spørsmålet som nå må besvares, er hvorvidt den genetiske variasjonen er av betydning for disse pasientenes respons på immunterapier retter mot B-celler, sier Harbo.

LITTERATUR:

1. Steri M, Orrù V, Idda ML et al. Overexpression of the cytokine BAFF and autoimmunity risk. N Engl J Med 2017;376: $1615-26$.

Publisert: 26. juni 2017. Tidsskr Nor Legeforen. DOI: 10.4045/tidsskr.17.0443

(C) Tidsskrift for Den norske legeforening 2020. Lastet ned fra tidsskriftet.no 